\title{
Pengaruh Profitabilitas dan Ukuran Perusahaan Terhadap Pengungkapan Corporate Social Responsibility (CSR) pada Perusahaan Pertambangan di Bursa Efek Indonesia
}

\author{
Entin Rukmana ${ }^{1}$, Edduar Hendri ${ }^{2}$, Rismansyah ${ }^{3}$ \\ ${ }^{1}$ Fakultas Ekonomi dan Bisnis Universitas PGRI Palembang, entinruk@gmail.com \\ ${ }^{2}$ Fakultas Ekonomi dan Bisnis Universitas PGRI Palembang, hendri edduar@yahoo.com \\ ${ }^{3}$ Fakultas Ekonomi dan Bisnis Universitas PGRI Palembang, rismansyah1972@gmail.com
}

\begin{abstract}
The purpose of this study is to examine the effect of profitability and company size on disclosure of corporate social responsibility (CSR) in mining companies listed on the Indonesia Stock Exchange (BEI) for the period 2016-2018. The population in this study were mining companies listed on the IDX for the 2016-2018 period which consisted of 47 companies, of which 15 companies were taken as many as 15 companies that met the criteria to be used as research samples with 3 periods of research years $(15 \times 3)$ resulting in 45 research data. . The data analysis technique used is descriptive statistical analysis, multiple regression analysis by first doing the classical assumption test consisting of normality test, multicollinearity test, heteroscedasticity test and autocorrelation test. The results showed that partially profitability did not have a significant effect on CSR disclosure. Company size partially does not have a significant effect on CSR disclosure. Profitability and company size simultaneously do not have a significant effect on CSR disclosure.
\end{abstract}

Keywords: Profitability, Company Size and Corporate Social Responsibility (CSR).

\begin{abstract}
ABSTRAK
Tujuan dari penelitian ini adalah untuk menguji pengaruh Profitabilitas dan Ukuran Perusahaan terhadap Pengungkapan Corporate Social Responsibility (CSR) pada perusahaan pertambangan yang terdaftar di Bursa Efek Indonesia (BEI) periode 2016-2018. Populasi dalam penelitian ini adalah perusahaan pertambangan yang terdaftar di BEI periode 2016-2018 yang terdiri dari 47 perusahaan, dari 47 perusahaan diambil sebanyak 15 perusahaan yang memenuhi kriteria untuk dijadikan sampel penelitian dengan 3 periode tahun penelitian $(15 \times 3)$ sehingga menghasilkan data sebanyak 45 data penelitian. Teknik analisis data yang digunakan adalah analisis statistik deskriptif, analisis regresi berganda dengan terlebih dahulu melakukan uji asumsi klasik yang terdiri dari uji normalitas, uji multikolinearitas, uji heteroskedastisitas dan uji autokorelasi.Hasil penelitian menunjukkan Profitabilitas secara parsial tidak berpengaruh signifikan terhadap pengungkapan CSR.Ukuran Perusahaan secara parsial tidak berpengaruh signifikan terhadap pengungkapan CSR.Profitabilitas dan Ukuran perusahaan secara simultan tidak berpengaruh signifikan terhadap pengungkapan CSR.
\end{abstract}

Kata Kunci: Profitabilitas, Ukuran Perusahaan dan Corporate Sosial Responsibility (CSR).

\section{A. PENDAHULUAN}

Perkembangan dunia saat ini menuntut perusahaan untuk meningkatkan perhatiannya kepada lingkungan sosial.Keberadaan perusahaan besar seperti perusahaan pertambangan di Indonesia diharapkan membawa perubahan dan pembangunan yang baik bagi kehidupan masyarakat sekitar. Perusahaan seharusnya tidak mementingkan kepentingan investor dan kreditor saja tetapi 
juga harus mementingkan karyawan, konsumen, masyarakat dan juga lingkungannya (Ismawati, 2017:21).

Beberapa fenomena kasus di Indonesia terkait permasalahan lingkungan sosial muncul karena dalam melaksanakan operasinya perusahaan kurang memperhatikan kondisi sekitarnya. Oleh sebab itu perusahaan dituntut untuk dapat lebih memperhatikan lingkungan sosial agar tercipta timbal balik antara perusahaan dengan lingkungan dan masyarakat.

Peristiwa di atas menjelaskan bahwa perusahaan tidak hanya dihadapkan pada tanggung jawab dalam perolehan keuntungan semata, perusahaan juga harus memperhatikan tanggung jawab sosial dan lingkungannya. Jika masyarakat menganggap perusahaan tidak memperhatikan aspek sosial dan lingkungannya serta tidak merasakan kontribusi secara langsung bahkan merasakan dampak negatif dari beroperasinya suatu perusahaan maka kondisi itu akan menimbulkan stigma negatif dikalangan masyarakat.

Salah satu bentuk pertanggungjawaban adalah dengan melakukan pengungkapan tanggung jawab sosial yang sering disebut Corporate Social Responsibility (CSR). Tanggung jawab sosial adalah sebuah pendekatan yang mengintegrasikan kepedulian sosial dalam perusahaan dan dalam interaksi dengan pemangku kepentingan (stakeholder) berdasarkan prinsip kesukarelaan dan kemitraan.

Penerapan CSR di Indonesia diatur dalam UU No. 40 Tahun 2007 tentang Perseroan Terbatas, yang menjelaskan tentang bagaimana tanggung jawab perusahaan terhadap lingkungan sosial.Perusahaan bertanggung jawab dalam permasalahan sosial dan lingkungan yang ditimbulkan dari pelaksanaan kegiatan perusahaan.

Pengungkapan Corporate Social Responsibility (CSR) sudah dianggap suatu kepentingan bagi perusahaan, selain sebagai bentuk ketaatan terhadap hukum tetapi juga untuk menjaga kelangsungan hidup perusahaan. Banyak manfaat yang diperoleh perusahaan dengan mengungkapkan CSR, antara lain; dapat meningkatkan citra perusahaan, dapat membawa keberuntungan perusahaan, dan dapat menjamin keberlangsungan perusahaan. Pentingnya pengungkapan CSR bagi perusahaan membuat banyak peneliti melakukan penelitian mengenai praktik perusahaan untuk mengungkapkan CSR.

Sulthony dan Adi (2019:9) hasil penelitian menunjukkan profitabilitas tidak berpengaruh terhadap pengungkapan CSR, sedangkan ukuran perusahaan, leverage, dan likuiditas berpengaruh terhadap pengungkapan CSR pada perusahaan Pertambangan. Prakasa dan Astika (2017:210) hasil penelitian menunjukkan profitabilitas dan kepemilikan manajemen berpengaruh positif terhadap pengungkapan CSR, sedangkan leverage tidak berpengaruh terhadap pengungkapan CSR pada perusahaan Pertambangan. Putri (2017:570) hasil penelitian menunjukkan ukuran perusahaan, profitabilitas, leverage, likuiditas, dan basis kepemilikan berpengaruh terhadap pengungkapan CSR pada perusahaan Pertambangan

Permasalahan perusahaan yang sering kali terjadi di Indonesia ialah kurangnya kesadaran dalam pengungkapan tanggung jawab sosial perusahaan.Karena perusahaan hanya mementingkan kepentingan investor dan kreditor saja tanpa mementingkan tanggung jawab sosialnya terhadap lingkungan dan masyarakat. Dalam pengungkapan CSR peneliti mengadopsi profitabilitas dan ukuran perusahaan sebagai variabel penelitian, karena ada 
beberapa perusahaan yang mungkin sudah memeliki profit yang tinggi dan ukuran perusahaan yang besar tetapi pengungkapan CSRnya masih kecil atau tidak sebanding dengan pendapatan perusahaan.

\section{B. KAJIAN TEORI \\ Profitabilitas}

Hery (2017:7) profitabilitas merupakan kemampuan suatu perusahaan untuk mendapatkan laba dalam suatu periode tertentu. Rasio profitabilitas mengukur efektifitas manajemen berdasarkan hasil pengembalian yang diperoleh. Hal ini ditunjukkanoleh laba yang dihasilkan dari penjualan dan pendapatan investasi. Profitabilitas juga merupakan salah satu dasar penilian kondisi perusahaan. oleh karena itu dibutuhkan suatu alat analisis untuk bisa menilainya. Alat analisis yang dimaksud adalah rasio-rasio keuangan.

Hery (2017:32) profitabilitas merupakan rasio yang menggambarkan kemampuan perushaan dalam menghasilkan laba melalui semua kemampuan dan sumber yang dimilikinya. Rasio dalam penelitian ini yang digunakan untuk mengukur profitabilitas perusahaan adalah alat ukur ROA. ROA digunakan untuk mengukur seberapa besar jumlah laba bersih yang akan dihasilkan dari setiap rupiah dana yang tertanam dalam total aset.

Adapun rumus profitabilitas adalah sebagai berikut:

$$
\text { ROA }=\frac{\text { Laba Bersih }}{\text { Total Asset }}
$$

\section{Ukuran Perusahaan}

Hery (2017: 97) ukuran perusahaan merupakan skala yang menunjukkan besar atau kecilnya suatu perusahaaan. Besar (Ukuran) perusahaan dapat dinyatakan dalam total aset, penjualan, dan kapitalisasi pasar. Ukuran Perusahaan melalui total aset lebih cenderung stabil daripada melalui penjualan. Hal ini disebabkan karena penjualan cenderung lebih berfluktuasi setiap tahun daripada total aset. Perusahaan besar cenderung lebih menarik dan lebih diperhatikan oleh publik. Perusahaan besar akan melakukan pengungkapan tanggung jawab sosial yang lebih banyak daripada perusahaan kecil.

Luasnya pengungkapan CSR tergantung dari ukuran perusahaan. Semakin besar ukuran entitas maka pengungkapan CSR-nya akan semakin tinggi dan sebaliknya jika semakin rendah ukuran suatu entitas maka pengungkapan CSRnya semakin kecil. Hal tersebut dikarenakan perusahaan yang besar akan menghadapi tanggung jawab yang lebih besar kepada masyarkat dan lingkungan untuk berprilaku positif.

Adapun rumus ukuran perusahaan sebagai berikut:

$$
\text { Ukuran Perusahaan }=\text { Ln ( total asset) }
$$

\section{Pengertian Corporate Social Responsibility (CSR)}

Hery (2017:104) mendefinisikan CSR adalah tanggung jawab sebuah organisasi terhadap dampak-dampak dari keputusan-keputusan dan kegiatankegiatannya pada masyarakat dan lingkungan yang diwujudkan dalam bentuk perilaku transparan dan etis yang sejalan dengan pembangunan berkelanjutan termasuk kesehatan dan kesejahteraan masyarakat. 
Mardikanto (2018:85) CSR adalah salah satu strategi yang dilakukan perusahaan untuk tetap mempertahankan eksistensi bisnisnya.Perusahaan tidak lagi dihadapkan pada tanggung jawab yang berpijak pada single bottom line, yaitu hanya pada kondisi keuangan. Namun, dengan berkembangnya konsep Triple Bottom Line yang dikemukakan oleh John Elkington pada tahun 1997, perusahaan kini dihadapkan pada tiga konsep yaitu profit (keuntungan), people (manusia), dan planet (lingkungan).

\section{Kerangka Pemikiran}

\section{Gambar Kerangka Pemikiran}

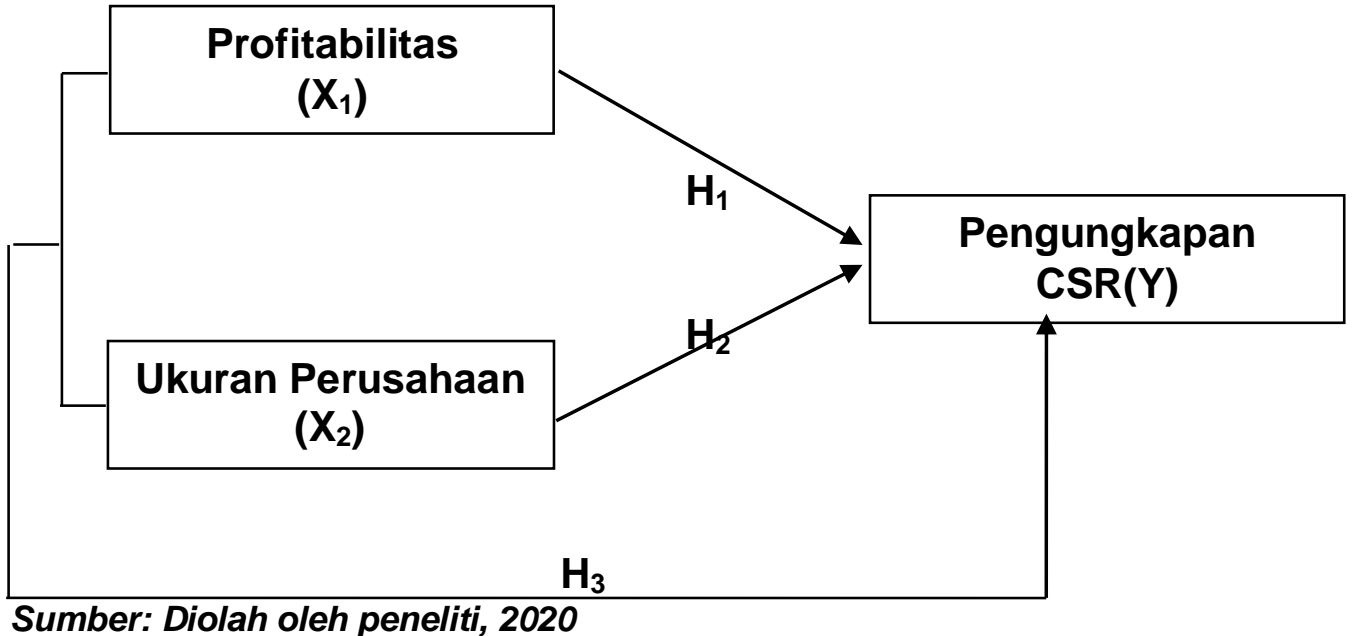

\section{Hipotesis Penelitian}

Sugiyono (2018:134) hipotesis merupakan jawaban sementara terhadap rumusan masalah penelitian,di mana rumusan masalah penelitian telah dinyatakan dalam bentuk kalimat pertanyaan.

Berdasarkan uraian di atas, maka hipotesis yang diuji dalam penelitian ini adalah: $\mathrm{H}_{1}$ : Diduga profitabilitas berpengaruh terhadap pengungkapan CSR.

$\mathrm{H}_{2}$ : Diduga ukuran perusahaan berpengaruh terhadap pengungkapan CSR.

$\mathrm{H}_{3}$ :Diduga profitabilitas dan ukuran perusahaan berpengaruh terhadap pengungkapanCSR

\section{METODE PENELITIAN}

Siregar (2017:16-17) metode penelitian dikelompokkan menjadi 2, yaitu Data Kualitatif dan Data Kuantitatif. Metode yang akan digunakan dalam penelitian ini adalah kuantitatif, karena data yang diteliti berupa angka. Sesuai dengan bentuknya, data kuantitatif dapat diolah atau dianalisis dengan menggunakan teknik perhitungan statistik.karena analisis kuantitatif dilakukan menggunakan Program for Special Science (SPSS) sebagai alat untuk menguji data yang ada.

\section{1) Populasi}

Sugiyono (2017:80) populasi adalah wilayah generalisasi yang terdiri atas objek atau subjek yang mempunyai kualitas dan karakteristik tertentu yang ditetapkan oleh peneliti untuk dipelajari dan kemudian ditarik kesimpulannya. 
Populasi yang akan diteliti adalah perusahaan pertambangan tahun 2016-2018 di Bursa Efek Indonesia yang terdiri atas 47 perusahaan.

\section{2) Sampel}

Sujarweni (2019:81) sampel adalah bagian dari jumlah dan karakteristik yang dimiliki oleh populasi yang digunakan untuk penelitian.Dari 47 perusahaan diambil sampel adalah 15 perusahaan yang memenuhi kriteria untuk dijadikan sampel.

Seleksi Sampel

\begin{tabular}{|c|c|}
\hline Keterangan & Jumlah \\
\hline $\begin{array}{l}\text { Perusahaan pertambangan yang terdaftar di Bursa Efek } \\
\text { Indonesia tahun } 2016-2018 \text {. }\end{array}$ & 47 \\
\hline $\begin{array}{l}\text { Perusahaan yang tidak menyediakan informasi laporan } \\
\text { tahunan yang lengkap dan yang tidak mengungkapkan } \\
\text { tanggung jawab sosial pada tahun 2016-2018. }\end{array}$ & $(32)$ \\
\hline Jumlah Sampel & 15 \\
\hline
\end{tabular}

Sumber: Bursa Efek Indonesia diolah, 2020

Perusahaan pertambangan yang terdaftar di Bursa Efek Indonesia periode 2016-2018 adalah 47 perusahaan. Berdasarkan kriteria diatas dapat disimpulkan bahwa jumlah sampel pada penelitian ini adalah 15 perusahaan yang memenuhi kriteria $\times 3$ tahun periode penelitian $(2016-2018)=45$ data penelitian.

\section{3) Sumber Data}

Siregar (2017:16) sumber data dalam penelitian ini adalah data sekunder yaitu Data yang diterbitkan atau digunakan oleh organisasi yang bukan pengolahnya atau yang tidak langsung memberikan data kepada pengumpulan data, misalnya lewat orang lain atau lewat dokumen.

\section{4) Teknik Pengumpulan Data}

a. Dokumentasi

Merupakan pengumpulan data yang dilakukan dengan mencari dokumendokumen perusahaan yang diperlukan dalam membahas masalah objek yang dilakukan.jenis data dokumentasi berupa faktur, jurnal, surat-surat, notulen hasil rapat, memo, atau dalam bentuk laporan program.

b. Studi Pustaka

Sebagai landasan teori yang akan digunakan dalam menganalisis data. Dasar-dasar studi pustaka diperoleh dari buku, literatur maupun tulisantulisan yang berhubungan dengan penelitian.Dari penjelasan di atas penulis mencari sumber data dari jurnal, dan buku-buku yang berhubungan dengan permasalahan penelitian.

\section{5) Teknik Analisis Data}

Jenis penelitian yang akan digunakan dalam penelitian ini adalah penelitian asosiatif, karena untuk mengetahui pengaruh variabel bebas yaitu profitabilitas dan ukuran perusahaan terhadap pengungkapan CSR pada perusahaan pertambangan yang terdaftar di Bursa Efek Indonesia tahun 2016-2018. Dalam menganalisis data peneliti menggunakan program SPSS versi 22 sebagai alat untuk menguji data yang ada.

\section{$>$ Statistik Deskriptif}

Priyatno (2018:124) statistik deskriptif memberikan gambaran tentang distribusi frekuensi variabel-variabel penelitian, nilai maksimum, minimum, 
rata-rata dan standar deviasi.Statistik deskriptif dapat digunakan bila hanya ingin mendeskripsikan data sampel, dan tidak ingin membuat kesimpulan yang berlaku untuk populasi di mana sampel diambil.

\section{$>$ Uji Asumsi Klasik}

Priyatno (2018:126-144) menjelaskan asumsi klasik terdiri dari beberapa uji sebagai berikut:

\section{$>$ Uji Normalitas}

Merupakan hal penting karena dengan data yang terdistribusi normal maka data tersebut dianggap dapat mewakili populasi.dalam penelitian ini normalitas data diuji menggunakan uji liliefors dengan kolmogorov-smirnov.

Tabel Hasil Uji Normalitas Data One-sample Kolmogorov-smirnov Setelah Data Ditransformasikan

\begin{tabular}{|c|c|c|c|c|}
\hline & & LN_X1 & LN_X2 & LN_Y \\
\hline $\mathbf{N}$ & & 45 & 45 & 45 \\
\hline \multirow{2}{*}{$\begin{array}{c}\text { Normal } \\
\text { Parameters }\end{array}$} & Mean & -3.2377 & 2.9877 & -2.0210 \\
\cline { 2 - 5 } & Std.Deviation & 1.35519 & 0.21070 & 0.22831 \\
\hline $\begin{array}{c}\text { Most } \\
\text { Extreme } \\
\text { Differences }\end{array}$ & Absolute & 0.101 & 0.126 & 0.118 \\
\cline { 2 - 5 } & Positive & 0.081 & 0.114 & 0.115 \\
\hline Test Statistic & Negative & -0.101 & -0.126 & -0.118 \\
\hline $\begin{array}{c}\text { Asymp. Sig. } \\
\text { (2-tailed) }\end{array}$ & & 0.101 & 0.126 & 0.118 \\
\hline \multirow{2}{*}{ (2uyyyy} & & 0.200 & 0.073 & 0.133 \\
\hline
\end{tabular}

\section{Sumber: Data Sekunder diolah, 2020}

Setelah data ditransformasikan maka sesuai dengan hasil pengujian OneSample Kolmogorov-Smirnov, maka bisa ditarik kesimpulan jika data sampel telah memenuhi kriteria residual berdistribusi normal yang nilai signifikansinya diatas 0,05.

\section{$>$ Uji Multikolinieritas}

Metode uji multikolinieritas yang umum dilihat dari nilai Tolerance danVIF.Jika nilai tolerance lebih dari 0,1 dan nilai VIF kurang dari 10, maka dapat disimpulkan tidak terjadi multikolinieritas pada model regresi.

Tabel Hasil Uji Multikolinieritas

\begin{tabular}{|c|c|c|}
\hline Variabel & Tolerance & VIF \\
\hline Profitabilitas (ROA) & 0.998 & 1.002 \\
\hline $\begin{array}{c}\text { Ukuran Perusahaan } \\
\text { (Size) }\end{array}$ & 0.998 & 1.002 \\
\hline
\end{tabular}

Sumber: Data sekunder diolah,2020

Berdasarkan tabel diketahui bahwa variabel Profitabilitas mempunyai nilai tolerance sebesar 0.998 dan nilai VIF sebesar 1.002, variabel Ukuran Perusahaan mempunyai nilai tolerance sebesar 0.998 dan nilai VIF sebesar 1.002. Dengan demikian kedua variabel bebas tersebut menunjukkan nilai Tolerance dan VIF diatas 0,10 dan dibawah 10, sehingga dapat disimpulkan bahwa tidak terjadi multikolinearitas. 


\section{Uji Heteroskedastisitas}

Adalah keadaan dimana dalam model regresi terjadi ketidaksamaan varian dari residual pada satu pengamatan ke pengamatan yang lain. Model regresi yang baik adalah tidak terjadi heteroskedastisitas. Jika nilai signifikansi antara variabel independen dengan absolut residual lebih besar dari 0,05 , tidak terjadi heteroskedastisitas.

Tabel Hasil Uji Heteroskedastisitas

\begin{tabular}{|c|c|c|c|}
\hline Variabel & Signifikan & $\boldsymbol{\alpha}=\mathbf{0 . 0 5}$ & Keterangan \\
\hline Profitabilitas (ROA) & 0.529 & 0.05 & $\begin{array}{c}\text { Tidak terjadi } \\
\text { heteroskedasitas }\end{array}$ \\
\hline $\begin{array}{c}\text { Ukuran } \\
\text { Perusahaan (Size) }\end{array}$ & 0.567 & 0.05 & $\begin{array}{c}\text { Tidak terjadi } \\
\text { heteroskedasitas }\end{array}$ \\
\hline
\end{tabular}

Sumber: Data sekunder diolah, 2020

Berdasarkan tabel diatas dapat disimpulkan bahwa nilai signifikansi dari variabel independen lebih besar dari 0,05 (sig > 0,05) dengan demikian bahwa model regresi yang dipakai tidak terjadi heteroskedastisitas.

\section{> Uji Autokorelasi}

Adalah hubungan yang terjadi antara residual dari pengamatan satu dengan pengamatan yang lain. Model regresi yang baik adalah yang tidak memiliki masalah autokorelasi.dilihat dari nilai Durbin Watson. Jika nilai Durbin Watson berada di antara -2 sampai +2 dapat disimpulkan bahwapenelitian ini tidak terjadi autokorelasi.penelitian ini tidak terjadi autokorelasi.

Tabel Hasil Uji Autokorelasi

\begin{tabular}{|c|c|c|}
\hline Variabel & DW & Keterangan \\
\hline ROA & 1.151 & $\begin{array}{r}\text { Tidak terjadi } \\
\text { Autokorelasi }\end{array}$ \\
\hline SIZE & 1.199 & $\begin{array}{r}\text { Tidak terjadi } \\
\text { Autokorelasi }\end{array}$ \\
\hline ROA dan SIZE & 1.186 & $\begin{array}{l}\text { Tidak terjadi } \\
\text { Autokorelasi }\end{array}$ \\
\hline
\end{tabular}

Sumber: Data sekunder diolah,2020

Berdasarkan tabel diketahui nilai DW ROA sebesar 1.151, nilai DW sebesar Size 1.199 dan nilai DW ROA dan Size sebesar 1.186. Nilai masing-masing terletak diantara -2 sampai +2.Sehingga dapat disimpulkan bahwa model regresi ini tidak terjadi autokerelasi.

\section{UJI REGRESI}

Hasil Uji Regresi Berganda

Tabel Hasil Uji Regresi Linear Berganda

\begin{tabular}{|l|c|}
\hline \multicolumn{1}{|c|}{ Variabel } & Nilai \\
\hline$\alpha$ (konstanta) & 0.152 \\
\hline Profitabilitas (ROA) & 0.071 \\
\hline Ukuran perusahaan (SIZE) & -0.001 \\
\hline Error & 0.0316813206 \\
\hline
\end{tabular}

Sumber: Data sekunder diolah, 2020 
Berdasarkan tabel dapat disimpulkan bahwa nilai konstanta sebesar 0.152 dan nilai koefisien masing-masing variabel sebesar 0.071 untuk variabel Profitabilitas, $-0,001$ untuk variabel Ukuran Perusahaan. Maka model regresi untuk penelitian ini adalah sebagai berkut:

CSR $=0.152+0,071 X_{1}-0,001 X_{2}$

Hasil persamaan model regresi di atas dapat dijelaskan sebagai berikut:

1. Nilai konstanta di atas sebesar 0.152, nilai tersebut memberikan pengertian bahwa jika variabel profitabilitas dan ukuran perusahaan sebesar 0, maka variabel pengungkapan Corporate Social Responsibility memiliki nilai 0.152 .

2. Nilai beta variabel profitabilitas yaitu sebesar 0.071 , nilai tersebut memberikan pengartian bahwa jika profitabilitas mengalami kenaikan 1000 poin maka Corporate Social Responsibility akan meningkat sebesar 71 poin.

3. Nilai beta variabel ukuran perusahaan yaitu sebesar -0.001 , nilai tersebut memberikan pengartian bahwa jika ukuran perusahaan mengalami penurunan 1000 poin maka Corporate Social Responsibility akan menurun sebesar -1 poin.

\section{Koefisien Korelasi}

Koefisien korelasi digunakan untuk mengetahui kuat atau tidaknya hubungan antara satu variabel dengan variabel yang lain.

Tabel Hasil Uji Koefisien Korelasi

\begin{tabular}{|c|c|c|c|}
\hline Variabel & $\begin{array}{c}\text { Pearson } \\
\text { Correlation }\end{array}$ & $\begin{array}{c}\text { Signifikan } \\
\mathbf{0 , 0 5}\end{array}$ & $\begin{array}{c}\text { Tingkat } \\
\text { Hubungan }\end{array}$ \\
\hline ROA terhadap CSR & 0.157 & 0.303 & Sangat Rendah \\
\hline Size terhadap CSR & -0.143 & 0.348 & Sangat Rendah \\
\hline
\end{tabular}

Sumber: Data sekunder diolah,2020

Berdasarkan tabel menunjukkan bahwa ROA terhadap CSR diperoleh Pearson Correlation sebesar 0.157 dengan nilai signifikan $0.303>0.05$ maka dapat disimpulkan bahwa hubungan ROA terhadap CSR sangat rendah. Untuk Size terhadap CSR diperoleh Pearson Correlation sebesar 0.143 dan nilai signifikan $0.348>0.05$ maka dapat disimpulkan bahwa hubungan Size dan CSR sangat rendah.

\section{Uji Koefisien Determinasi $\left(\mathbf{R}^{2}\right)$}

Koefisien determinasi digunakan untuk menguji seberapa besar pengaruh variabel independen terhadap variabel dependen.

Tabel Hasil Uji Koefisien Determinasi

\begin{tabular}{|c|c|c|c|c|c|}
\hline Variabel & $\mathbf{R}$ & $\begin{array}{c}\mathbf{R} \\
\text { Square }\end{array}$ & $\begin{array}{c}\text { Adjusted R } \\
\text { Square }\end{array}$ & $\begin{array}{c}\text { Std. Error of } \\
\text { the estimate }\end{array}$ & $\begin{array}{c}\text { Durbin } \\
\text { Watson }\end{array}$ \\
\hline $\begin{array}{c}\text { X1-LnX1 } \\
\text { X2-LnX2 }\end{array}$ & 0.209 & 0.043 & -0.002 & 0.0316813206 & 1.186 \\
\hline
\end{tabular}

Sumber: Data sekunder diolah, 2020 
Berdasarkan hasil pengujian diatas, diperoleh hasil Adjusted $R$ Square pada perusahaan Pertambangan yang terdaftar di BEI sebesar 0.043 yang berarti sebesar $4.3 \%$. Oleh karena itu, dapat disimpulkan bahwa sebesar $4.3 \%$ CSR yang di proksikan dengan nilai discretionary accrual dipengaruhi oleh profitabilitas dan ukuran perusahaan. Sedangkan sisanya sebesar $95.7 \%$ dipengaruhi oleh variabel lain selain variabel yang digunakan dalam penelitian ini.

\section{Pengujian Hipotesis}

Uji T

Uji statistik T digunakan untuk mengetahui apakah secara parsial variabel independen berpengaruh secara signifikan atau tidak terhadap variabel dependen.

\begin{tabular}{|c|c|c|c|}
\multicolumn{4}{c}{ Tabel Hasil Uji T (Parsial) } \\
\hline Variabel & Signifikan & $\boldsymbol{\alpha}=\mathbf{0 . 0 5}$ & Keterangan \\
\hline Profitabilitas (ROA) & 0.321 & 0.05 & Tidak Signifikan \\
\hline $\begin{array}{c}\text { Ukuran Perusahaan } \\
\text { (Size) }\end{array}$ & 0.368 & 0.05 & Tidak Signifikan \\
\hline
\end{tabular}

Sumber: Data sekunder diolah, 2020

Berdasarkan tabel dapat ditarik kesmipulan sesuai dengan kriteria pengambilan keputusan sebagai berikut:

1. Variabel Profitabilitas memiliki nilai signifikan sebesar 0.321 . Nilai signifikan $0.321>0.05$. Artinya $\mathrm{H}_{\mathrm{o}}$ diterima dan $\mathrm{H}_{\mathrm{a}}$ ditolak. Dapat disimpulkan variabel profitabilitas tidak berpengaruh signifikan terhadap pengungkapan CSR.

2. Variabel Ukuran Perusahaan memiliki nilai signifikan sebesar 0.368. Nilai signifikan $0.368>0.05$. Artinya $\mathrm{H}_{\circ}$ diterima dan $\mathrm{H}_{a}$ ditolak. Dapat disimpulkan variabel ukuran perusahaan tidak berpengaruh signifikan terhadap pengungkapan CSR.

\section{Uji F}

Uji statistik $F$ digunakan untuk mengetahui apakah variabel independen berpengaruh signifikan secara simultan terhadap terhadap variabel dependen.

Tabel Hasil Uji F (Simultan)

\begin{tabular}{|c|c|c|c|}
\hline Variabel & Signifikan & $\mathbf{\alpha}=\mathbf{0 . 0 5}$ & Keterangan \\
\hline $\begin{array}{c}\text { Profitabilitas dan } \\
\text { Ukuran } \\
\text { Perusahaan }\end{array}$ & 0.393 & 0.05 & Tidak Signifikan \\
\hline
\end{tabular}

Sumber: Data sekunder diolah, 2020

Berdasarkan tabel variabel Profitabilitas dan Ukuran Perusahaan secara simultan memiliki nilai signifikan sebesar 0.393. Nilai signifikan $0.393>$ 0.05.Dapat disimpulkan bahwa variabel profitabilitas dan ukuran perusahaan secara simultan tidak berpengaruh signifikan terhadap pengungkapan CSR. 


\section{HASIL PENELITIAN}

1. $\mathrm{H}_{1}$ :Berdasarkan hasil penelitian Profitabilitas memiliki nilai signifikan sebesar 0.321. Nilai signifikan $0.321>0.05$. Artinya $\mathrm{H}_{\circ}$ diterima dan $\mathrm{H}_{a}$ ditolak. Dapat disimpulkan variabel profitabilitas secara parsial tidak berpengaruh signifikan terhadap pengungkapan CSR.

2. $\mathrm{H}_{2}$ : Berdasarkan hasil penelitian Ukuran Perusahaan memiliki nilai signifikan sebesar 0.368. Nilai signifikan $0.368>0.05$. Artinya $\mathrm{H}_{0}$ diterima dan $\mathrm{H}_{a}$ ditolak. Dapat disimpulkan variabel ukuran perusahaan secara parsial tidak berpengaruh signifikan terhadap pengungkapan CSR.

3. $\mathrm{H}_{3}$ : Berdasarkan hasil penelitian Profitabilitas dan Ukuran Perusahaan secara simultan memiliki nilai signifikan sebesar 0.393. Nilai signifikan $0.393>0.05$. Dapat disimpulkan bahwa variabel profitabilitas dan ukuran perusahaan secara simultan tidak berpengaruh signifikan terhadap pengungkapan CSR.

\section{E. PEMBAHASAN}

a) Pengaruh Profitabilitas Terhadap Pengungkapan CSR

Variabel profitabilitas memiliki nilai signifikansi 0.321 lebih besar dari 0.05 , itu artinya $\mathrm{H}_{\mathrm{o}}$ diterima dan $\mathrm{H}_{\mathrm{a}}$ ditolak. Hasil uji statistik menunjukkan bahwa variabel profitabilitas tidak berpengaruh signifikan terhadap variabel CSR. Nilai ini menunjukkan bahwa perusahaan akan tetap mengungkapkan tanggungjawab sosialnya tanpa memperhatikan besar kecilnya laba yang dihasilkan oleh perusahaan. Perusahaan yang memiliki profitabilitas tinggi merasa tidak perlu mengungkapkan aktivitas tanggung jawab sosialnya dengan asumsi para pembaca laporan tahunan sudah tertarik dengan pencapaian kinerja keuangan perusahaan yang baik.Sehingga pengungkapan CSR perusahaan hanya untuk memenuhi peraturan UU yang mengatur tentang tanggung jawab sosial dan lingkungan sehingga pengungkapan CSR merupakan program tahunan yang harus dilakukan. Hasil penelitian ini sejalan dengan penelitian Amrina Rosyada dan Fenty Astrina (2018), Mujiyati dan Refa Danang A(2019).

\section{b) Pengaruh Ukuran Perusahaan Terhadap Pengungkapan CSR}

Variabel Ukuran Perusahaan memiliki nilai signifikansi 0.368 lebih besar dari 0.05 , itu artinya $\mathrm{H}_{\mathrm{o}}$ diterima dan $\mathrm{H}_{\mathrm{a}}$ ditolak. Hasil uji statistik menunjukkan bahwa variabel Ukuran Perusahaan juga tidak berpengaruh signifikan terhadap variabel CSR. Dengan demikian pengungkapan CSR yang dilakukan oleh perusahaan tidak terkait dengan besar dan kecilnya ukuran perusahaan, karena ukuran perusahaan tidak hanya dilihat dari besar kecilnya aset yang dimiliki bisa juga dari rasio likuiditas, rasio solvabilitas, atau dari laba yang dimiliki. Hasil penelitian ini sejalan dengan penelitian Sulthony dan Adi (2019). Beberapa penelitian menunjukkan pengujian hipotesis yang dilakukan memiliki hasil yang berbeda pada variabel yang sama. Penelitian ini tidak sejalan dengan penelitian Putri (2017), Yurika dan Viriany (2019) yang hasil penelitiannya menyatakan bahwa variabel ukuran perusahaan berpengaruh terhadap pengungkapan CSR. 


\section{c) Pengaruh Profitabilitas dan Ukuran Perusahaan Terhadap Pengungkapan CSR}

Berdasarkan uji ANOVA atau uji $\mathrm{F}$ profitabilitas dan ukuran perusahaan memiliki nilai signifikan sebesar 0.393. Karena signifikan lebih besar dari 0.05 , itu artinya $\mathrm{H}_{\mathrm{o}}$ diterima dan $\mathrm{H}_{\mathrm{a}}$ ditolak maka dapat disimpulkan bahwa variabel profitabilitas dan ukuran perusahaan secara simultan tidak berpengaruh signifikan terhadap pengungkapan CSR pada perusahaan pertambangan yang terdaftar di Bursa Efek Indonesia periode 2016-2018. Hal ini dibuktikan pula dari hasil uji koefisien determinasi $R$ Square yang hanya sebesar $0.043(4.3 \%)$ menunjukkan rendahnya kemampuan variabel terikat dalam menjelaskan variabel bebas. Artinya variabel lain yang tidak diteliti persentasenya lebih dominan dipengaruhi oleh variabel lain di luar model penelitian sebesar $95.7 \%$.

\section{E. KESIMPULAN DAN SARAN}

\section{1) Kesimpulan}

Berdasarkan hasil penelitian dan pengujian mengenai variabel profitabilitas dan ukuran perusahaan terhadap pengungkapan CSR pada perusahaan pertambangan yang terdaftar di Bursa Efek Indonesia periode 2016-2018 maka dapat disimpulkan sebagai berikut:

a. Profitabilitas memiliki nilai signifikan sebesar $0.321>0.05$. Hipotesisnya $\mathrm{H}_{\circ}$ diterima dan $\mathrm{H}_{\mathrm{a}}$ ditolak. Artinya variabel profitabilitas secara parsial tidak berpengaruh signifikan terhadap pengungkapan CSRpada perusahaan pertambangan yang terdaftar di Bursa Efek Indonesia periode 2016-2018.

b. Ukuran Perusahaan memiliki nilai signifikan sebesar $0.368>0.05$. Hipotesisnya $\mathrm{H}_{\mathrm{o}}$ diterima dan $\mathrm{H}_{\mathrm{a}}$ ditolak. Artinya variabel ukuran perusahaan secara parsial tidak berpengaruh signifikan terhadap pengungkapan CSRpada perusahaan pertambangan yang terdaftar di Bursa Efek Indonesia periode 2016-2018.

c. Profitabilitas dan ukuran perusahaan secara simultan tidak berpengaruh signifikan terhadap pengungkapan CSR pada perusahaan Pertambangan yang terdaftar di Bursa Efek Indonesia periode 2016-2018. Besarnya pengaruh variabel-variabel bebas terhadap variabel terikat hanya $4.3 \%$ sedangkan sisanya $95.7 \%$.\% dipengaruhi oleh variabel lain.

\section{2) Saran}

a. Bagi perusahaan diharapkan biayaatas kegiatan CSR yang dikeluarkan dilaporkan secara jelas dalam laporan tahunan, agar dapat memberikan informasi yang utuh dan transparan kepada para pembaca laporan tahunan.

b. Bagi pemerintah diharapkan dapat membuat standar besarnya biaya CSR yang harus dikeluarkan oleh perusahaan paling tidak sesuai dengan hasil laba yang diperoleh.

c. Bagi peneliti selanjutnya diharapkan dapat menambah variabel-variabel independen lainya seperti rasio keuangan dan sebagainya yang di duga memiliki kekuatan lebih berpengarauh terhadap CSR dan menggunakan item pengukur yang lebih banyak dan detail, misalnya dengan mengadopsi GRI (Global Reporting Initiative) terbaru yang telah disesuaikan dengan kondisi pelaksanaan CSR di Indonesia sebagai item pengukur variabel dependen pada sustainability report perusahaan di Indonesia. 


\section{DAFTAR PUSTAKA}

Amrina, Rosyada dan Astrina Fenty. 2018. "Pengaruh Profitabilitas dan Ukuran Perusahaan terhadap Pengungkapan Tanggung Jawab Sosial pda Perusahaan Asuransi yang Terdaftar di Bursa Efek Indonesia". Jurnal Penelitian dan Pengembangan Akuntansi.

Hery. 2017. Kajian Riset Akuntansi. Jakarta: PT Grasindo.

Hery. 2017. Teori Akuntansi. Jakarta: PT Gramedia.

Mardikanto, Totok. 2018. Corporate Social Responsibility. Bandung: Alfabeta.

Prakasa, Sila dan Astika, Ida Bagus Putra. 2017. "Pengaruh Leverage, Profitabilitas, dan Kepemilikan Manajemen Pada Corporate Social Responsibility Disclosure Perusahaan Pertambangan". E-Jurnal Akuntansi Universitas Udayana. Volume 18, Nomor 1, 2017.

Priyatno, Duwi. 2018. Belajar Cepat Olah Data Statistik dengan SPSS. Yogyakarta: Andi.

Putri, Rindu Kurnia. 2017. "Pengaruh Ukuran Perusahaan, Profitabilitas, Leverage, Likuiditas, dan Basis Kepemilikan terhadap Corporate Social Responsibility pada Perusahaan Pertambangan yang Tedaftar di BEI".Jurnal JOM Fekon. Volume 4, Nomor 1, 2017.

Siregar, Syofian. 2017. Metode Penelitian Kuantitatif. Jakarta: PT Fajar Interpratama Mandiri.

Sugiyono. 2017. Metode Penelitian Kuantitatif, Kualitatif, dan R\&D. Bandung: Alfabeta

Sugiyono. 2018. Metode Penelitian Manajemen. Bandung: Alfabeta

Sujarweni, Wiratna. 2019. Analisis Laporan Keuangan. Yogyakarta: Pustaka Baru Press

Sulthony, Z. M., Adi, S.W. 2019. "Pengaruh Profitabilitas, Ukuran Perusahaan, Leverage dan Likuiditas Terhadap Pengungkapan Tanggung Jawab Sosial Perusahaan (Studi pada Perusahaan Pertambangan yang terdaftar di BEI Periode 2014-2016)". Universitas Muhammadiyah Surakarta. 